Frederic De Wispelaere, Gabriella Berki and Snjezana Balokovic

\title{
Montenegro's accession to the European Union: Possible consequences of the free movement of persons for the Montenegrin social security system
}

\begin{abstract}
This article discusses the potential impact of the free movement of persons in the EU on the Montenegrin social security system. It can be argued that three variables will be of great importance: 1) mobility between Montenegro and other EU member states; 2) social security legislation in Montenegro; and 3) the social security Coordination Regulations. The scale of migration will be highly dependent on whether there are transitional arrangements and whether neighbouring countries, not least Serbia, join the EU at the same time. In order to avoid an erosion of the workforce and consequently of people paying taxes in Montenegro, it might be useful to negotiate transitional arrangements as well as to promote other types of labour mobility, such as intra-EU posting. Furthermore, it can be expected that Montenegro's accession will have financial and administrative implications in the area of healthcare. After all, accession to the EU will lead to a further increase in the number of tourists and thus of the amount that Montenegro will have to recover from member states if unplanned healthcare has been provided in Montenegro.
\end{abstract}

Keywords: accession to the EU, free movement of persons, transitional arrangements, social security, European coordination of social security systems

Introduction

Accession negotiations between the EU and Montenegro were opened in June 2012. This implies that Montenegro has firstly to align its legislation with the EU's acquis and then to ensure its implementation and enforcement (Aspridis and Petrelli 2012). To date, 32 negotiating chapters have been opened, including chapter 2 on 'Freedom of movement for workers'.

The free movement of persons ${ }^{1}$ is one of the most fundamental freedoms in the $\mathrm{EU}$ and this would not be possible without the guarantee that citizens do not lose social security protection when moving to another member state. This objective has been materialised through the 'Basic' Regulation 883/2004 and the 'Implementing' Regulation 987/2009 (hereinafter jointly referred to as the 'Coordination Regula-

1 This embodies not only the free movement of workers but also of economically non-active people such as students and pensioners. 
tions'). In order to protect the social security rights of people moving within the $\mathrm{EU},{ }^{2}$ some key principles are set out in the Co-ordination Regulations (Fuchs and Cornelissen 2015):

1. prohibition of discrimination on the basis of nationality, complemented by the equal treatment of cross-border facts and events (i.e. principle of assimilation)

2. aggregation of periods

3. the exportability of benefits

4. the determination of a single applicable law.

The Coordination Regulations only 'coordinate' the various social security systems. Consequently, member states are still free to determine their own social security schemes and, consequently, to decide who is to be insured, what benefits should be granted, how they should be calculated and for how long they should be granted. Moreover, coordination can be applied only in respect of legislation concerning social benefits which are within the material scope of the Coordination Regulations. This covers the following branches of social security: sickness benefits; maternity and equivalent paternity benefits; invalidity benefits; old age benefits; survivors' benefits; benefits in respect of accidents at work and occupational diseases; death grants; unemployment benefits; pre-retirement benefits; and family benefits. Furthermore, the EU rules also apply to special non-contributory cash benefits but not to social and medical assistance or benefits in relation to which a member state assumes liability and provides compensation (e.g. war victims).

The mobility of people has increased significantly in the EU over the past decades. Consequently, the group of people protected by the Coordination Regulations is certainly not small and cannot be narrowed down to intra-EU migrants of working age. In fact, in the field of social security, the Coordination Regulations nowadays protect all EU citizens moving between member states, be it for reasons linked to work or indeed for others (holiday, planned healthcare, moving abroad as a retired person, etc.). Some figures serve to illustrate the scope of the European coordination system. In 2017, there were 19 million EU/EFTA movers ${ }^{3}$ within the EU/ EFTA, according to Eurostat population statistics, including 14 million people of working age (20-64 years). They made up 3.6 per cent of the total EU/EFTA population and 4.5 per cent of the total population of working age. In addition, there were some 1.9 million cross-border workers ${ }^{4}$ in the EU/EFTA in 2017, around 1.8 million

2 The Coordination Regulations not only apply to EU nationals but also to nationals of Norway, Iceland and Liechtenstein thanks to the Agreement on the European Economic Area (EEA), as well as to Swiss nationals by virtue of a bilateral agreement on free movement of persons. Additionally, since 1 January 2011, Regulation (EU) No. 1231/2010 has extended the scope of the Coordination Regulations to nationals of non-EU countries (third country nationals) legally resident in the EU and in a cross-border situation.

3 EU/EFTA movers: EU-28 or European Free Trade Area citizens (i.e. from Iceland, Liechtenstein, Norway or Switzerland) who reside in an EU-28 or EFTA country other than their one of their citizenship.

4 'Cross-border workers' are people who work in one EU/EFTA country but live in another. 
postings ${ }^{5}$ and, finally, some one million people who normally worked in two or more member states (Fries-Tersch et al. 2018; De Wispelaere et al. 2018a). Furthermore, EU/EFTA residents also made around 229 million trips with overnight stays in another EU/EFTA country - some 204 million tourist trips and around 25 million trips for business purposes (Eurostat data).

In addition, there is, of course, a significant flow of people from non-EU/EFTA countries to the EU. In order to safeguard the social rights of citizens who are mobile between an EU/EFTA country and a non-EU/EFTA country, bilateral agreements can be concluded. Currently, Montenegro has 19 bilateral social security agreements with EU/EFTA countries. ${ }^{6}$ Generally, these bilateral agreements have a narrower material scope compared to the Coordination Regulations. In addition, the provisions in these bilateral agreements often differ from those in the Coordination Regulations. Consequently, the broader material scope of the Coordination Regulations, as well as the differences in provision compared to bilateral agreements, will have an impact on the social security system of Montenegro when it joins the EU. However, it can also be expected that the evolution of the mobility of people to and from Montenegro will in particular have a financial impact on the Montenegrin social security system.

\section{Research approach}

\section{Research question}

We discuss in this article the potential impact of the free movement of persons on the social security system of Montenegro. ${ }^{7}$ Before Montenegro can become a member of the EU, it is obliged to take some legal/administrative steps in the area of free movement and the protection of social rights, among others. The 2019 follow-up report of the European Commission on Montenegro states that:

Some progress was made on freedom of movement for workers as concerns the coordination

of social security systems. (European Commission 2019: 56)

This concerns, in particular, the administrative steps which must be taken by the competent public authorities in Montenegro. They need to have sufficient knowledge on the matter and sufficient staff to handle the files, as well as sufficient ICT resources. All this will, of course, be determined to a large extent by how mobility evolves following accession. Therefore, this article focuses less on the administrative challenges that the free movement of persons will bring and more on the possible impact on the Montenegrin social security system, both in terms of the evolution of the

5 A 'posted worker' is an employee sent by his or her employer to carry out a service in another member state on a temporary basis.

6 Austria, Belgium, Bulgaria, Croatia, Czech Republic, Denmark, Germany, France, Hungary, Italy, Luxembourg, Norway, Poland, Slovakia, Slovenia, Sweden, The Netherlands, United Kingdom, Switzerland.

7 Our research is based on the results of the project 'Towards EU Rules on the Coordination of Social Security Schemes'. Thanks to Igor Ivanovic, Maria Kasarova and Ana Lakic for their support. 
number of people involved as well as the related public spending, and finally on how policy decisions can limit this impact.

In the next section, we describe the applied research methodology. Afterwards, the current state of play as well as the future impact on the Montenegrin social security system of the protection of cross-border social rights are discussed. The closing section formulates some thoughts around the policy role that transitional arrangements might play.

\section{Research methodology}

In order to analyse the potential (financial) impact of the free movement of persons on the Montenegrin social security system after joining the EU, it is important to have a good understanding of the factors that will determine this dependent variable. There are three important independent variables (see also Figure 1):

1. the scale of mobility between Montenegro and other EU member states

2. the content of the social security legislation in Montenegro

3. the provisions defined in the Coordination Regulations (and the differences with the bilateral agreements).

It can be assumed that the accession of Montenegro to the EU will have some important consequences for the mobility of people to and from Montenegro. However, it is not only the scale of (labour) mobility that will have an impact on the Montenegrin social security system. In addition, the content of the provisions of the Coordination Regulations, the extent to which EU provisions differ from those of the bilateral agreements and, finally, the social security legislation of Montenegro (in terms of its main conditions, qualifying periods, amounts, etc.) will all affect the dimensions of the impact on the Montenegrin social security system. Nonetheless, assessing the impact is very challenging, mainly because there is a number of uncertainties that will affect the outcome of the three independent variables and, thus, also the final outcome. For instance, the future evolution of mobility to and from Montenegro will depend on whether there are transitional arrangements (the free movement of workers may be deferred for a period of a maximum seven years) and whether other neighbouring countries, not least Serbia, will join the EU at the same time. 
Figure 1 - Variables determining the budgetary impact of the mobility of people through the application of the Coordination Regulations

\section{National social security legislation}

EU rules on the coordination of social security systems

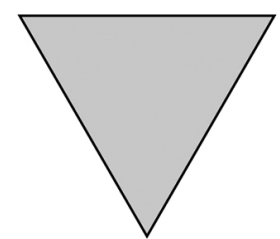

\section{Mobility flows from and to EU/EFTA countries}

\section{Methodology to define the social security legislation in Montenegro and its} expenditure

The Mutual Information System on Social Protection of the Council of Europe (MISSCEO) provides information on social protection in those countries of the Council of Europe that are not members of the EU's own MISSOC network (the Mutual Information System on Social Protection).

MISSCEO covers a total of twelve countries, including Montenegro, and produces updated comparative tables on social protection systems in the form of a database (similar to the tables within MISSOC). The following aspects are reported by the comparative tables of MISSCEO:

- distribution of cash versus in-kind benefits

- qualifying period

- eligibility criteria

- level of benefit.

These aspects will have an impact on total social expenses in Montenegro as well as on the financial impact of EU rules on the coordination of social security systems. For example, limited access to social allowances will apply not only to the local population but also to those who come to Montenegro to work, live and reside. This variable will probably remain rather stable before and after EU accession.

Until recently, consistent data on the extent of social expenditure in Montenegro were difficult to find (Government of Montenegro 2017, 2019; Eurostat 2017). The methodology for the collection of such data also differed from that followed by Eurostat on the European System of Integrated Social Protection Statistics (ESSPROS). However, Montenegro has been following the logic of the ESSPROS tables since 
2019, which is an important step forward (see also Kaluđerović and Golubović 2019). ${ }^{8}$

\section{Methodology to define current and future mobility to and from Montenegro}

Several national and European data sources are available to determine the current mobility of people (of working age) to and from Montenegro. For instance, relevant data are provided by the Statistical Office of Montenegro (Monstat). Nonetheless, we mainly refer to the data published at European level by Eurostat, the World Bank and the United Nations. ${ }^{9}$

Estimating the future scale of mobility is a very challenging task. For instance, the forecasted migration flow from the countries that joined the EU in 2004 and 2007 was severely underestimated. ${ }^{10}$ Generally, there are three methods which are used by scholars to forecast future migration from new countries to EU member states (Bauer and Zimmerman 1999; Boeri and Brücker 2001; Sinn 2004; Fertig and Kahanec 2015). The first - the so-called survey-based approach - estimates migratory potential on the basis of the responses of a representative sample of the population to a set of questions about their propensity to migrate. The second method is based on simple extrapolations of previous trends, particularly those similar in nature: for instance, the previous enlargement round. The third method utilises econometric models and links migration processes to a set of socio-economic factors in countries of origin and of destination.

In general, the results of the different analyses illustrate the difficulties in estimating the future scale of mobility: the outcomes are very sensitive to the assumptions being made and to the data used. Our predictions are, in the main, based on the evolution of the population in countries that have joined the EU in recent years, with a particular focus on Croatia.

Methodology to define current and future applicable rules in the case of mobility to and from Montenegro

As stated before, Montenegro has 19 bilateral social security agreements with EU/EFTA countries. It is important to know how the current bilateral agreements differ from each other, as well as to what extent they differ from EU provisions on social security coordination. Small differences will, consequently, have a smaller financial impact. Moreover, the countries to be covered will expand from 19 EU/EFTA

8 The legal basis for the implementation of social protection statistics in Montenegro (the ESSPROS methodology) is the Law on Official Statistics and Official Statistics System (Official Gazette of Montenegro No. 18/12) and the Annual Plan of Statistical Surveys for 2019 (Official Gazette of Montenegro No. 9/19). For more information and an overview of the data, see: https://www.monstat.org/eng/page.php?id=1563\&pageid=1563.

9 For an overview of relevant data sources, see Marchand et al. (2019).

10 For instance, Boeri and Brücker (2000) expected some 2.9 million EU-12 immigrants by the end of the first decade. However, according to Labour Force Survey data, within ten years of the 2004 enlargement, the total number of EU-12 nationals residing in the 'old' member states increased from 1.1 million in 2004 to 6.1 million in 2014 (cited from Fihel et al. 2015). Romania and Poland are the two main countries of origin (Eurostat data). 
countries to $32 \mathrm{EU} / \mathrm{EFTA}$ countries ( 31 excluding the UK). Consequently, the extent to which current bilateral agreements already cover the main flows of people will determine the size of the additional group which must be taken into consideration.

\section{Methodology to define current and future social expenditure by Montenegro related} to the cross-border context

The three independent variables described above can be used to estimate the financial impact on the social security system once Montenegro has joined the EU. However, bringing these together in one econometric model is a challenging task and falls outside the ambitions of this article. We prefer here to report figures on the current social expenditure by Montenegro related to the application of the bilateral agreements; and, secondly, to estimate the future social expenditure after joining the EU based on figures from member states that have recently joined the EU.

Based on a detailed questionnaire addressed to a selection of competent public authorities in Montenegro (the Ministry of Labour and Social Welfare; the Health Insurance Fund; and the Pension and Disability Insurance Fund), data were collected on the number of people who currently benefit from these bilateral agreements as well as on the expenditure by Montenegro related to the application of these. Nonetheless, it should be noted that we encountered some difficulties in collecting the data. This is largely due to the various administrations in Montenegro not yet being familiar with such questionnaires.

Our projections are, largely, based on data collected by the Network of experts on statistics on the free movement of workers and social security coordination (see also De Wispelaere and Pacolet 2018a). ${ }^{11}$ Data from the network provide us with information on the number of people who benefit from the application of the Coordination Regulations as well as on the related budgetary impact. Consequently, these data are very useful for the calculation of the possible financial impact on the social security system of Montenegro. They serve as a 'frame of reference' by looking at the European average or at specific data from EU/EFTA countries similar to Montenegro.

\section{State of play}

This section discusses the current situation in Montenegro in terms of social security expenditure; mobility to and from Montenegro; and, finally, the impact of the stocks and flows of transnational mobility on the Montenegrin social security system.

11 The network was set up by European Commission DG Employment, Social Affairs and Inclusion and consists of experts from HIVA (KU Leuven), Milieu Ltd, IRIS (UGent), Szeged University and Eftheia on social security coordination and the free movement of workers. For an overview of network publications, see: https://hiva.kuleuven.be/en/news/ne wsitems/Reports-on-social-security-coordination-and-intra-EU-labour-mobility-20171212. 


\section{The social security system in Montenegro}

In 2017, social protection expenditure in Montenegro amounted to $€ 723 \mathrm{~m}$, i.e. some 17 per cent of GDP (Monstat data; Kaluđerović and Golubović 2019). This percentage is well below that of the EU-28 average (28 per cent of GDP), but is still higher in comparison with several other member states, such as Romania (14.4 per cent), Latvia (14.9 per cent), Ireland (14.9 per cent), Lithuania (15.1 per cent), Estonia (16 per cent), Malta (16.1 per cent) and Bulgaria (16.8 per cent) (Eurostat data).

The main cost items in the Montenegrin social security system are pensions and healthcare (Monstat data). In 2017, €438m was spent on old age, survivors' and invalidity pensions; while $€ 200 \mathrm{~m}$ went on healthcare. Considerably less was spent in the other branches of social security (for instance, just $€ 15 \mathrm{~m}$ went on unemployment benefits). Often, access to the other branches of social security is also restricted or otherwise the amount of benefit is not particularly generous. For instance, access to family benefit in Montenegro is means-tested ${ }^{12}$ while unemployment benefits are paid at a low level and are limited in time. ${ }^{13}$ Even so, public spending related to family benefits amounted to some $€ 56 \mathrm{~m}$ in 2017.

\section{Mobility to and from Montenegro}

Figures show that the mobility of people (of working age) who move from the EU to Montenegro is currently marginal compared to the mobility of people (also of working age) from extra-EU neighbouring countries. The share of foreigners in the total population of Montenegro amounts to between eight and fourteen per cent, depending on the source. ${ }^{14}$ Only some three per cent of the population in Montenegro are EU/EFTA movers, most of them from Croatia. In absolute figures, the migrant stock in Montenegro is estimated at 90,209 people, of whom 14,992 have come from Serbia and 29,462 from Bosnia and Herzegovina (World Bank data).

Furthermore, the vast majority of people with a work permit come from outside the EU. In 2018, a total of 19,200 work permits were issued by Montenegro, accounting for eight per cent of total formal employment in Montenegro (Ministry of Internal Affairs data). Most of the work permits were issued to people from Serbia $(8,422$ people), Bosnia and Herzegovina $(3,019)$, Albania $(2,183)$ and, finally, Kosovo $(1,553)$. Only 293 work permits were issued to EU/EFTA movers, the largest number coming from Croatia (87).

12 In terms of child allowance for social assistance beneficiaries: the amount of average monthly income in the previous quarter may not exceed the base rate of $€ 67.89$ to $€ 129.06$ applied for the award of this benefit. There is no means testing for beneficiaries where there is a child entitled to care assistance allowance or to disability allowance or for orphans (MISSCEO).

13 Unemployment benefit amounts to forty per cent of the minimum wage determined under the General Collective Agreement (MISSCEO).

14 According to data from Eurostat [migr_pop1ctz], eight per cent of people residing in Montenegro have foreign nationality. However, in their 2017 International Migration Report, the United Nations stated that migrants amount to 11.3 per cent of the total population in Montenegro. Finally, according to the World Bank, the share of foreigners in the total population of Montenegro totals 14.5 per cent. 
Finally, there were 1.9 million tourist arrivals in Montenegro in 2017 (Monstat data). Almost seven out of ten tourists arriving in Montenegro came from an extra EU/EFTA country. Some 531,650 tourists came from an EU/EFTA country, of whom the largest numbers were from France $(60,865$ people), Germany $(57,813)$ and Poland $(56,061)$ (Eurostat data). These figures concerning the scale of movements into Montenegro clearly show that the mobility of tourists from the EU to Montenegro is at a much higher level than the mobility of EU movers of working age or of temporary EU workers.

Furthermore, based on World Bank data from the 2018 Bilateral Migration Matrix, the stock of Montenegrins residing in EU/EFTA countries amounts to 87,000 people. Most are living in Croatia $(39,357$ people), Germany $(22,000)$ and, to a lesser extent, Luxembourg $(9,065)$. However, a much larger group of Montenegrins are living in extra-EU neighbouring countries, with some 70,700 people living in Serbia alone. Thus, the outflow of people from Montenegro seems to be higher than the inflow. However, this also represents a historical distortion given the existence of close ties with the neighbouring countries.

\section{Impact of mobility on the Montenegrin social security system}

The above figures on the stocks and flows of migrants influence the social expenditure by Montenegro on people in cross-border situations. However, the current impact of mobility on the Montenegrin social security system can only be assessed to a limited extent since, for most branches of social security, we only have an idea of the numbers circulating between Montenegro and other countries. For instance, this is important in the area of instances of cross-border healthcare provided to people staying or residing in a country other than the competent country, ${ }^{15}$ or the pensions paid to people residing in another country. Consequently, the amount of social benefits provided to migrants residing in Montenegro for which Montenegro is also the competent country is not known, as no breakdown is available by nationality or by country of origin/birth. This is a considerable limitation.

Total cross-border healthcare expenditure by Montenegro amounted to $€ 6 \mathrm{~m}$ in 2016 , of which $€ 5.6 \mathrm{~m}$ was related to the reimbursement of healthcare provided in an extra-EU country, most of all in Serbia. This implies that only seven per cent of the cost of cross-border healthcare is related to EU member states. The annual cost of cross-border healthcare might be underestimated on the basis of other figures we have received. Based on a national document on the Montenegrin budget for 2017 (Government of Montenegro 2017), we find that approximately $€ 10 \mathrm{~m}$ is listed for the reimbursement of healthcare abroad. Overall, the level of cross-border healthcare to be reimbursed by Montenegro accounts for about three per cent of its total healthcare expenditure, of which only 0.2 per cent applies to the EU.

Due to the inflow of tourists being larger than the outflow, Montenegro is expected to be a 'creditor country' instead of a 'debtor country' with regard to the reimbursement of unplanned cross-border healthcare. However, the bilateral agreements

15 The 'competent country' refers to the country where the person concerned is insured at the time of the application for benefit. In this case, Montenegro will be the competent country. 
with the UK and Poland are based on the principle of reciprocity, which means that the healthcare costs are borne by the member state where healthcare was provided. Thus, while every year many tourists from both countries go on holiday to Montenegro, this means that, for a significant portion of foreign people who might need health treatment in Montenegro, no reimbursement can be requested by Montenegro. This is financially disadvantageous.

Furthermore, approximately 9,400 pensioners entitled to a Montenegrin pension lived abroad in 2017. This represents 7.6 per cent of the total number of pensioners to whom Montenegro is paying a pension. However, only 1,675 pensioners who lived abroad reside in the EU, some 1.4 per cent of the total. The total amount exported abroad amounts to $€ 10 \mathrm{~m}$, of which $€ 1.8 \mathrm{~m}$ goes to pensioners residing in the EU. This represents just 2.6 per cent of total expenditure on old age, survivors' and invalidity pensions, with exports to the EU accounting for 0.5 per cent of the total pensions expenditure. This lower percentage for expenditure compared to the number of pensioners living in the EU can be explained by the amounts sent abroad being in respect only of partial pensions; in most cases, an additional amount will be paid by one or more other countries where the pensioner has been insured.

Periods of insurance, employment or self-employment completed by a worker in other countries are aggregated in relation to the calculation of an unemployment benefit in only a limited number of cases. In 2017, just nine cases were reported where periods in Croatia or Slovenia were added to the period worked in Montenegro. The result is that only 0.1 per cent of people who became unemployed in Montenegro proved that they had periods of insurance, employment or self-employment abroad in order to be able to receive unemployment benefit from Montenegro. This is not really surprising as most bilateral agreements do not define provisions regarding the aggregation of periods for unemployment benefit.

Finally, the public authorities were not aware of any cases in which unemployment benefit, family allowance or maternity leave from Montenegro was exported to another country. This is mainly because most of the bilateral agreements which have been concluded between Montenegro and other countries simply do not allow this. For instance, only the bilateral agreement with Italy envisages the exporting of unemployment benefit. Furthermore, the bilateral agreements with Hungary, Slovenia and Austria contain no provisions on family benefits. The bilateral agreements with most countries define that, where a person is entitled to family benefit in both states, the one responsible is that in which the child resides.

\section{Estimated impact in the case of Montenegro joining the EU}

In our theoretical framework, we defined three independent variables that may, to a large extent, determine the impact of the free movement of persons on the Montenegrin social security system. In this section, we will elaborate on these in detail, excluding Montenegro's national social security legislation since this is unlikely to change. We focus in particular on the impact of transitional measures that may restrict the free movement of persons for a certain period of time. In order to estimate the extent of future stocks and flows, as well as their financial impact, particular attention will be paid to the experience of countries that joined the EU recently. 


\section{Differences between bilateral agreements and EU rules on the coordination of social security systems}

A detailed analysis of the 19 bilateral social security agreements signed between Montenegro and EU/EFTA countries shows that such agreements have a narrower material scope compared to the Coordination Regulations. For instance, paternity benefits, pre-retirement benefits and special non-contributory benefits are not covered by the material scope of bilateral agreements. Moreover, the provisions of bilateral agreements in respect of the coordination of social security systems frequently differ from those of the Coordination Regulations, in particular when coordinating the entitlement and payment of unemployment benefits and family benefits.

The number of people who may benefit from the cross-border social protection of the Coordination Regulations, as well as the impact on the budget of the Montenegrin social security system, is likely to be influenced by the following factors:

1. the rules will apply to many more countries than the 19 member states with which there is a bilateral agreement

2. the material scope will be much broader

3. the provisions of the Coordination Regulations will often be defined differently.

Free movement of workers and the impact of transitional arrangements

Push and pull factors

Migration to and from a country is influenced by a combination of push and pull factors (Kapural 2005; Bonin et al. 2008; Vidovic and Mara 2015; Gubert and Senne 2016; Migali and Scipioni 2018; Rojas-Romagosa and Bollen 2018). In that regard, it is useful to have an overview of the indicators that might affect future inwards and outwards migration decisions between Montenegro and EU/EFTA countries, such as wages and unemployment rates.

Data from Monstat (from 2017) show that average gross wages in Montenegro amount to $€ 765$ and net wages to $€ 510$. Median earnings in the EU are approximately three times higher than median earnings in Montenegro (Eurostat data). Median earnings in Germany, which will probably be one of the most popular countries for Montenegrins looking to move abroad, are nearly four times higher. Additionally, median earnings in Croatia are some 45 per cent higher than in Montenegro. At the same time, in comparison with other neighbouring countries such as Macedonia and Serbia, median and average earnings in Montenegro are twenty to thirty per cent higher. Moreover, it should be noted that average and median wages in Montenegro would not be the lowest in the EU when the country joins the EU: Bulgaria, Romania, Lithuania, Latvia and Hungary all have lower median wages.

Research shows that young people of working age tend to be more mobile compared to older people (Fries-Tersch et al. 2018; Vidovic and Mara 2015). Hence, a high youth unemployment rate in the current country of residence might reinforce the intention to migrate. Unemployment in Montenegro is at a much higher level than in the EU-28, particularly compared to Germany. Moreover, in 2016, youth unemployment even amounted to 36 per cent in Montenegro, a figure almost double the average youth unemployment rate in the EU (18.7 per cent) (Eurostat data). Mon- 
tenegro's unemployment figures should be interpreted with a degree of caution as a (high) number of unemployed Montenegrins will actually be employed in the informal economy (Katnić 2016). Nevertheless, the above figures show that the expected probability of finding employment, as well as the expected standard of living, might be perceived to be higher in the EU than in Montenegro.

Impact of the labour market and the importance of transitional arrangements

A less commonly investigated aspect of the free movement of persons is how it affects labour markets in countries of origin. In general, free movement is considered to have a win-win character for both origin and host countries. However, such a belief needs to be nuanced not only by the perspective of the host country but also by that of the country of origin: the freedom to move to another member state might be beneficial for the emigrant, but not necessarily for the country of origin (Elsner 2012; Krastev 2017) ${ }^{16}$ In particular, there are concerns that emigration may lead to 'brain drain', labour shortages and a worsening of the demographic outlook in the country of origin (Bagatelas and Sergi 2003; Goldner Lang 2007); while, likewise, the country of origin might experience a decrease in tax income and in domestic consumption..$^{17}$ At the same time, there are also several advantages: when labour market distortions arise, the free movement of workers can help mitigate the costs through a more efficient allocation of labour across the EU. Furthermore, remittances from people working in other EU countries provide additional income for households in the country of origin. ${ }^{18}$ At present, the rate of dependency on remittances (i.e. the share of inflows in personal remittances as a percentage of the respective country's GDP) already amounts to as much as 10.7 per cent of GDP in Montenegro (2017 figures). This very high percentage will probably increase further when Montenegro joins the EU.

Transitional arrangements can be defined as a means of limiting the inflow or outflow of people during the first years of the accession of a new country to the EU. In line with agreed transitional arrangements, the free movement of workers (and services) into the EU may be deferred in respect of a new country for a period of a maximum seven years, divided into three distinct phases according to the ' $2+3+2$ ' formula.

16 Krastev (2017: 53) argues that 'The biggest beneficiaries of the opening of the borders turned out to be the brilliant individual émigrés, the bad eastern European politicians, and the xenophobic western European parties. Twenty five years later, many eastern European have started to have second thoughts about how much their countries have truly benefited from a regime of openness.'.

17 'Nations and states have an unfortunate habit of disappearing in the recent history of eastern and central Europe. In the last twenty-five years, around 10 per cent of Bulgarians have left the country in order to live and work abroad' (Krastev 2017: 50). 'But mass emigration, mostly of people between the ages of twenty five and fifty, has dramatically hurt Bulgaria's economy and politics' (Krastev 2017: 52).

18 Holland et al. (2011) argue that remittances can partially offset the negative impact on growth in the short to medium-term, but they cannot fully address the loss of labour input to capacity output in the longer-term. 
Transitional arrangements are mainly implemented to avoid labour market disruption in the host country (EC 2001). ${ }^{19}$ According to Fihel et al. (2015: 7) there are two main reasons why transitional arrangements may be important to a host country:

First, there is the rationale related to the impact of migration on the host countries in terms of their labour market and the welfare of their nationals. Second, there are arguments resulting from public fears (in fact also somehow related to the first case but seriously fuelled by the political process).

However, the implementation of transitional arrangements might also result in several advantages and disadvantages for the country of origin (Elsner 2012), as Table 1 sets out. That an erosion of the workforce, and consequently of people paying taxes in the country of origin, is avoided or, at least, delayed is probably the most important advantage of the implementation of transitional arrangements for the country of origin. ${ }^{20}$ This gives new EU member states time to convince their citizens to stay, or at least to promote other types of labour mobility, such as cross-border work, seasonal work or intra-EU posting (De Wispelaere and Pacolet 2020). For instance, posted workers remain attached to the social security scheme in their country of origin (for a maximum of 24 months). This also means that the posted worker and the posting undertaking pay social security contributions in the country of origin.

Table 1 - Transitional arrangements from the perspective of the country of origin

\begin{tabular}{|l|l|}
\hline \multicolumn{1}{|c|}{ Pros } & \multicolumn{1}{c|}{ Cons } \\
\hline $\begin{array}{l}\text { Avoid/delay erosion of the workforce, the } \\
\text { 'brain drain' and, consequently, of people } \\
\text { paying taxes }\end{array}$ & $\begin{array}{l}\text { Not possible to correct the labour market (high } \\
\text { unemployment rate - inequality between } \\
\text { demand and supply of work) }\end{array}$ \\
\hline $\begin{array}{l}\text { Benefit from the economic consequences of } \\
\text { EU accession (increased imports, increased } \\
\text { tourism, etc.) leading to increased } \\
\text { employment }\end{array}$ & Amount of remittances will be (much) lower \\
\hline
\end{tabular}

19 Nevertheless, the implementation of transitional arrangements has led to the use of several loopholes. A report published by the European Commission in 2006 stated that it was 'Acknowledged that the restrictions may have encouraged EU-8 nationals to look for other ways to perform economic activity in EU-15 Member States, reflected in an exceptionally high influx of posted workers or workers claiming to be self-employed.' This phenomenon can be conceptualised as the 'front door/back door' problem. In the same report, the social partners also pointed out that restrictions had led to a proliferation of undeclared work and bogus employment. Moreover, according to Holland et al. (2011) there was a significant diversion from 'traditional' destinations (Germany) to new labour markets (particularly the UK).

20 However, research and recent data show that transitional measures only temporarily postpone migration and, consequently, have only a limited effect on the long-run stock of immigrants (Boeri and Brücker 2000; Eurostat data). 
Gives more time to convince people to stay and promote alternatives: providing services in another member state by posting;

employment as a cross-border worker

Forecasts of mobility to and from Montenegro

On average, the population in the countries that accessed the EU in 2004, 2007 or 2013 decreased by some one per cent during the first five years after accession (Eurostat data). However, there are strong differences among the countries that joined the EU in these years: Romania, Bulgaria, Lithuania, Croatia, Latvia, Poland and Estonia experienced a (strong) decrease in their population during the first five years after accession; in contrast, Cyprus, Slovenia, Slovakia and Malta showed a positive evolution of their population.

The above results show that the outcome is highly uncertain, dependent on several push and pull factors. It seems plausible to us that the Montenegrin population will remain stable or show a small increase. The primary reason is that Montenegrins will use other forms of labour mobility, including cross-border, seasonal work and intraEU posting, which will keep them resident in Montenegro (De Wispelaere and Pacolet 2020). This assumption is supported by wages and prices being mostly lower in Montenegro than in EU member states. This makes it profitable to work in another EU member state (for instance, in Croatia and Germany), but still live in Montenegro. Another reason why Montenegro's population might increase depends on whether or not other neighbouring countries join the EU at the same time. For instance, if Serbia joins the EU together with Montenegro it might result in a strong incoming flow of Serbians on the labour market. Moreover, based on recent results of the 'Potential Net Migration Index' published by Gallup, the Montenegrin adult population would increase by 25 per cent if all adults moved to where they wanted. ${ }^{21}$

Finally, on the basis of projections, it can be expected that the number of tourists from the EU/EFTA will further increase, to 850,000 people in 2028. ${ }^{22}$ Montenegro's accession to the EU will further strengthen this growth. The increase in the number of tourists from the EU/EFTA will have a significant impact on the administrative burden as more claims for the reimbursement of cross-border healthcare will be issued by Montenegro to EU/EFTA countries.

21 https://news.gallup.com/poll/245270/newest-potential-net-migration-index-shows-gains-los ses.aspx

22 By 2028, international tourist arrivals in Montenegro are forecast to total 3,003,000 (World Travel \& Tourism Council), an increase of some sixty per cent. If we assume that arrivals from the EU will increase by a similar percentage, there will be some 850,000 tourists from EU/EFTA countries in 2028. However, it can be expected that the number of tourists from EU/EFTA member states will increase even further when Montenegro joins the EU. 
Financial impact of the free movement of persons on the Montenegrin social security system

Data collected from EU/EFTA countries show that the financial impact of the application of the Coordination Regulations is, in most countries, very small (De Wispelaere et al. 2018a). Only those countries with a high number of incoming crossborder workers, such as Luxembourg and Switzerland, experience a relatively high impact in terms of the percentage of total social expenditure accounted for under the Regulations. This is because these countries often pay cash benefits, such as family allowance, maternity leave benefit, pensions, etc., to families living in another member state. However, the financial impact of incoming EU/EFTA migrants on the social security systems of EU/EFTA countries cannot be estimated exhaustively.

It can be expected that the financial implications of Montenegro's accession to the EU will lie mainly in the area of healthcare. Due to the large number of tourists who, it is anticipated, will travel to Montenegro each year, we expect that the claims for the reimbursement of healthcare provided in Montenegro will increase significantly. This is also something we have observed in Croatia and other Mediterranean countries (De Wispelaere et al. 2018b). Furthermore, under the Coordination Regulations, the costs of healthcare provided by a foreign public healthcare provider are fully reimbursed by the competent member state in accordance with its own treatment tariffs (Berki 2018). This principle facilitates the free movement of persons, enforces the social rights of EU citizens and visualises the social character of the Coordination Regulations. The cost of medical treatment being higher in many countries compared to Montenegro will, of course, also have financial implications for social security in Montenegro. Notably, the full reimbursement of the costs of medical treatment provided by the member state in which treatment has taken place will need to be provided by Montenegro in accordance with the tariffs of that member state, not with those applying in Montenegro. Figures for Bulgaria and Romania show that this can have a high budgetary impact: both show cross-border expenditure on unplanned healthcare reaching more than one per cent of total healthcare spending related to benefits in kind (De Wispelaere et al. 2018b).

Finally, it is important to stress the importance of stability in the financing of the Montenegrin social security system. As noted before, the determination of a single competent member state is one of the key principles of the Coordination Regulations. The determination of the applicable legislation is not only an important issue for a person exercising mobility rights, since it has an impact on which country's social protection can be enjoyed, but also for the member states concerned since it determines where social security contributions have to be paid. In the case of employment, the legislation of the member state where the activity is carried out usually applies (lex loci laboris). If the outflow of persons is higher than the inflow, the financing of social protection may thus be jeopardised. There will also be a reduction in expenditure, although such savings will be outweighed by the loss of income. Above all, outflows will mainly concern people of working age. This shows the importance of keeping people of working age within a country's social security system (OECD 
2013). ${ }^{23}$ In the case of Montenegro, this may come under pressure in terms of accession to the EU. In the final section, we engage in some discussion into the role of transitional arrangements in avoiding the difficulties raised by this situation.

\section{Some recommendations}

It can be argued that the change in (labour) mobility between Montenegro and other EU countries will, in particular, have a budgetary impact on the Montenegrin social security system when it joins the EU. In that regard, we disagree with the conclusion of Goldner Lang (2007: 264) that 'The issue of free movement of labour in the enlarged Union is a political rather than an economic and social question.' Indeed, the objective should be to keep stability in the level of social protection receipts and expenditure in Montenegro at the time of accession to the EU and in subsequent years.

Theoretically, it is possible to delay the full application of the principle of freedom of movement for workers (and services) from a new EU member state for a period of a maximum seven years. Transitional arrangements are, in the main, defined to protect the labour markets of current EU member states. However, experience teaches us that accession to the EU mostly influences the labour markets of those member states that join the EU. After all, the several countries that joined the EU in 2004, 2007 and 2013 experienced a strong wave of emigration. The introduction of transitional measures may, therefore, also be useful for new member states.

Kapural (2005: 101) argues that:

Accession negotiations give a perfect opportunity to negotiate the best possible transitional arrangement.

However, based on policies followed in the past, it might be the case that the EU has no intention of defining transitional arrangements for Montenegro. During the enlargement of the EU in 2004, Sweden, Ireland and the UK decided not to apply restrictions on access to their labour markets by EU-8 nationals. All other EU-15 member states maintained the principle that a work permit was required to access their labour market. Nonetheless, no transitional arrangements were put in place for Cyprus and Malta. Due to the population in Montenegro being about the same as in these two countries, it might be the case that no transitional arrangements will be proposed by the EU. ${ }^{24}$ The question is whether the Montenegrin government should have the same opinion.

23 Research from the OECD (2013) shows that the fiscal effects of immigrants are relatively modest and in the range of some one per cent of GDP. This is confirmed by more recent research. Nyman and Ahlskog (2018) show that, for the majority of EU member states, the net fiscal effects of hosting EU migrants have been moderately positive across the time period 2004-2015. For most, the net fiscal effects of EU migrants appear to be around 0.5 per cent of GDP.

24 However, wages and prices in Cyprus and Malta are (much) higher than in Montenegro (Eurostat data). This might underpin any decision by the EU to define transitional arrangements for Montenegro. 


\section{References}

Aspridis, G and M. Petrelli (2012) 'When the EU met the western Balkans: Ready for the wedding?' SEER Journal for Labour and Social Affairs in Eastern Europe 15(1): 5-26.

Bagatelas, W and B. Sergi (2003) 'The Balkans "Brain Drain" - Its Meaning and Implications' SEER Journal for Labour and Social Affairs in Eastern Europe 6(4): 7-12.

Bauer, K and K. F. Zimmerman (1999) Assessment of Possible Migration Pressure and its Labour Market Impact Following EU Enlargement to Central and Eastern Europe IZA Research Report: Bonn.

Berki, G (2018) Free movement of patients in the EU Intersentia: Cambridge.

Boeri, T and H. Brücker (2000) The Impact of Eastern Enlargement on Employment and Labour Markets in the EU Member States DIW \& IGIER on behalf of the European Commission.

Boeri, T and H. Brücker (2001) Eastern Enlargement and EU Labour Markets: Perceptions, Challenges and Opportunities IZA Discussion Paper Series No. 256.

Bonin, H, W. Eichhorst, C. Florman, M. O. Hansen, K. Skiöld, J. Stuhler, K. Tatsiramos, H. Thomasen and K. F. Zimmermann (2008) 'Geographic Mobility in the European Union: Optimising its economic and social benefits' IZA Research Report No. 19, Bonn.

De Wispelaere, F and J. Pacolet (2020) 'The Benefits of Posting. Facts and Figures on the Use and Impact of Intra-EU Posting' in J. Arnholtz and N. Lillie (Eds.) Posted Work in the European Union: The Political Economy of Free Movement Routledge.

De Wispelaere, F, J. Pacolet and L. De Smedt (2018a) Social security coordination at a glance. Reference year 2017 Network Statistics FMSSFE, on behalf of DG EMPL - European Commission.

De Wispelaere, F, J. Pacolet and L. De Smedt (2018b) Cross-border healthcare in the EU under social security coordination. Reference year 2017 Network Statistics FMSSFE, on behalf of DG EMPL - European Commission.

Elsner, B (2012) Does Emigration Benefit the Stayers? Evidence from EU Enlargement IZA Discussion Paper Series No. 6843.

European Commission (2001) Information Note on the Free Movement of Workers in the Context of Enlargement Brussels.

European Commission (2006) Report on the Functioning of the Transitional Arrangements set out in the 2003 Accession Treaty (period 1 May 2004 - 30 April 2006), $\operatorname{COM}(2006) 48$, Brussels.

European Commission (2019) Montenegro 2019 Report. Accompanying the document Communication from the Commission to the European Parliament, the 
Council, the European Economic and Social Committee and the Committee of the Regions 2019 Communication on EU Enlargement Policy SWD(2019) 217 final.

Eurostat (2017) Key figures on enlargement countries European Union.

Fertig, M and M. Kahanec (2015) Projections of potential flows to the enlarging EU from Ukraine, Croatia and other Eastern neighbors IZA Journal of Migration $4(6)$.

Fihel, A, A. Janicka, P. Kaczmarczyk and J. Nestorowicz (2015) Free movement of workers and transitional arrangements: Lessons from the 2004 and 2007 enlargements on behalf of DG EMPL - European Commission.

Fries-Tersch, E, T. Tugran, L. Rossi and H. Bradley (2018) 2017 Annual report on intra-EU labour mobility Network Statistics FMSSFE, European Commission.

Fuchs, M and R. Cornelissen (2015) EU Social Security Law. A Commentary on EU Regulations 883/2004 and 987/2009 Nomos - C.H. Beck - Hart Publishing.

Goldner Lang, I (2007) 'Transitional arrangements in the enlarged European Union: How free is the free movement of workers?', Croatian Yearbook of European Law \& Policy 3(3): 241-271.

Government of Montenegro (2017) 'Montenegro Fiscal Strategy 2017-2020' Official Gazette of Montenegro No. 52/2017.

Government of Montenegro (2019) Montenegro Economic Reform Programme 2019-2021 Podgorica.

Gubert, F and J. Senne (2016) Is the European Union attractive for potential migrants? An investigation of migration intentions across the world OECD Social Employment and Migration Working Papers No. 188, OECD Publishing: Paris.

Holland, D, T. Fic, P. Paluchowski, A. Rincon-Aznar and L. Stokes (2011) Labour Mobility within the EU: The Impact of Enlargement and Transitional Arrangements NIESR Discussion Paper No. 379, National Institute of Economic and Social Research: London.

International Organization for Migration (2015) Labour Mobility as a Factor of Development in South-East Europe SEE2020 Series.

Kaluđerović, J and V. Golubović (2019) Financing social protection in Montenegro ESPN report.

Kapural, M (2005) 'Freedom of movement of workers in the enlarged European Union and its effect on Croatia' in K. Ott (Ed.) Croatian Accession to the European Union: Facing the Challenges of Negotiations pp. 85-107.

Katnić, M (2016) Informal work: from challenges to solutions UNDP.

Krastev, I (2017) After Europe University of Pennsylvania Press.

Marchand, K, V. Fajth, and M. Siegel (2019) Relevant Data to Understand Migration in the EU Reminder project. 
Migali, S and M. Scipioni (2018) A global analysis of intentions to migrate JRC Technical Reports, JRC111207, European Commission.

Nyman, P and R. Ahlskog (2018) Fiscal effects of intra-EEA migration Working Paper, Reminder-project.

OECD (2013) International Migration Outlook 2013 OECD Publishing.

Paunović, S and R. Kosanović (2019) 'Further milestones in the economic development of south-eastern Europe' SEER Journal for Labour and Social Affairs in Eastern Europe 22(1): 33-52.

Rojas-Romagosa, $\mathrm{H}$ and J. Bollen (2018) Estimating migration changes from the EU's free movement of people principle CPB Discussion Paper No. 385, CPB Netherlands Bureau of Economic Policy Analysis.

Sinn, H (2004) EU enlargement, migration and the new constitution CESifo Working Paper No. 1367, Munich.

Vidovic, H and I. Mara (2015) Free movement of workers, transitional arrangements and potential mobility from Croatia Vienna Institute for International Economic Studies on behalf of DG EMPL - European Commission.

Regulation (EC) No 883/2004 of the European Parliament and of the Council of 29 April 2004 on the coordination of social security systems.

Regulation (EC) No 987/2009 of the European Parliament and of the Council of 16 September 2009 laying down the procedure for implementing Regulation (EC) No 883/2004 on the coordination of social security systems.

EU Mutual Information System on Social Protection (MISSOC) https://www.missoc. org/.

Mutual Information System on Social Protection of the Council of Europe (MISSCEO) http://www.missceo.coe.int/. 